\title{
Effect of Electrically Precipitated Fly Ash(EPFA) On Fresh and Hardened Properties of High Strength Self- Compacting Concrete
}

Sambangi Arunchaitanya ( $\sim$ arunchaitanya0@gmail.com )

JNTUA College of Engineering https://orcid.org/0000-0002-2342-3933

E. Arunakanthi

JNTUA: Jawaharlal Nehru Technological University Anantapur

\section{Research Article}

Keywords: Self-Compacting Concrete, Compressive strength, L-Box, U-Box, Slump Flow, Sorptivity, RCPT

Posted Date: February 23rd, 2021

DOI: https://doi.org/10.21203/rs.3.rs-216368/v1

License: (c) (i) This work is licensed under a Creative Commons Attribution 4.0 International License.

Read Full License 


\section{Abstract}

Concrete is the most common heterogeneous material in the construction industry. Admixtures have gained wide use in modern constructions, which are having congested reinforcement with ambitious casting conditions. For such applications, self-compacting concrete (SCC) is the only special concrete, which can have high cohesiveness and fluidity. This paper shows the study on the fresh properties, compressive, flexural and split tensile strength in addition to RCPT, sorptivity of SCC with partially replaced electrically precipitated fly ash (EPFA) from 0 to $30 \%$ at $5 \%$ interval in cement and polycarboxylate ether-based superplasticizer as a chemical admixture. Compared the results with conventional SCC mix the fresh concrete performance was studied through the measurement of passing ability, filling ability and flowing ability by using L-Box, U-Box, V-Funnel and slump flow. The results showed that $20 \%$ EPFA as partial replacement to SCC gives better results than the conventional concrete, thereby leading to economical profits as well as ecological benefits.

\section{Introduction}

In general, concrete is known to be used extensively as composite material all over the world, due to its adaptability made by a primary component called cement. However, Portland cement production shows a severe effect on the environment. In cement manufacturing, a massive quantity of $\mathrm{CO}_{2}$ is being emitted into the troposphere, which causes high carbon footprints. So, there is an immediate need to find an alternate or secondary cementitious material (SCM) to reduce this emission[1-3].

SCC can be defined as concrete, which flows and fills around the formwork, consolidated by its own weight without any conventional vibrations and also shows resistance to bleeding or segregation[4]. SCC contains large quantities of fine materials than the normally vibrated concrete, in addition to superplasticizers and viscosity modifying agents. The performance of fresh SCC will be depended upon the properties of the cement, and the chemical admixtures used[5-7]. In the construction industry, several varieties of superplasticizers were using to obtain various strengths of SCC. These can have either long chain or short chain of molecules. Among these chemical admixtures comprised of long chains of molecules, which can show the effect on free water content[8-10]. To achieve the fresh performances (i.e., filling ability, passing ability, and flowing ability) cement, fine aggregate is increased in the mix, due to this, manufacturing price of a concrete mixture is relatively higher than convention concrete[44]. By adding mineral admixtures as SCM will help to get SCC in economical[11-13, 46]. Fly ash is the most reliable and easily accessible industrial waste product. Fly ash could boost the workability of a mix because of its surface area, which could be higher than cement[14-17].

SCM shows their effect not only on rheological properties but also on strength and durability parameters. Due to the higher surface area of fly ash, the voids present in the concrete would be filled. The strength parameters could be improved by adding the SCM at the particular limit; by this, there may be a possibility to develop high strength concretes[18-21, 48]. 
Studies have shown that by the usage of fly ash, fresh and mechanical properties has been increasing. Uysal.et.al.[22] studied about the fresh, strength, depth of carbonation by the increase of fly ash content from $15 \%$ to $35 \%$ with an interval of $5 \% .20 \%$ replacement obtained better workability and, $15 \%$ shows high mechanical properties. Higher levels of Fly ash makes concrete impermeable[23]. Interaction between cement and superplasticizer may be affected due to the addition of fly ash and also acts as an agent to reduce water-cement ratio without effecting setting times[24]. The voids present in the concrete were reduced with the help of pozzolanic material(Fly ash) by the formation of denser calcium silicate hydrates (C-S-H)[25]. Jongsung Sim.et.al[26] substituted fly ash in cement at $0 \%, 15 \%$ and $30 \%$ while using recycled coarse aggregate. It was observed that by the increase of fly ash percentage with recycled aggregates shows better results. Compressive strength improved at $15 \%$ and long term strengths were good at $30 \%$ replacements. $30 \%$ shows the highest resistance against chloride penetration. Lu.et.al[27] increased the levels of fly ash at $0 \%, 15 \%, 30 \%$ and $45 \%$ to study carbonation depth, pH levels. From the results, it was concluded that maximum fly ash content reduced the carbonation depth and increased the alkalinity of the concrete. A. Bagheri. et al. [28] compared the performance of electrical coefficient, chloride ion penetration, and strength at the ages of $7,28,90,180$ days of concrete with coarse fly ash and fine fly ash at the levels of $15 \%$ and $30 \%$. By the increase of fly ash along with age, increment showed better performance.

In the previous literature, it was observed that many studies went for using fly ash as mineral admixture and also several combinations were used in binary, ternary blended concrete. But, now, with the enhanced technology chemical admixtures are playing a vital role in concrete technology. Modified polycarboxylate ether-based superplasticizer is available in the market, which may eliminate the usage of viscosity modifying agents. The present study is to know the effect of partially replaced SCC while using modified polycarboxylate ether-based superplasticizer by electrically precipitated fly ash(EPFA) on the water content required for cement paste, setting time, fresh, mechanical and transport performance. The workability parameters were noticed through U-Box height difference, L-Box depth ratio, V-Funnel time and slump flow time. Durability characteristic Rapid Chloride Penetration Test(RCPT), Water sorptivity were determined.

\section{Novelty Of The Research}

The research mainly aims on the utilization of electrically precipitated fly ash (EPFA) in self compaction concrete and to elucidate its behavior. Though studies showed improved strength of concrete using fly ash in concrete, a little studies have been done on EPFA utilization in self compacting concrete. The durability behavior of EPFA substituted SCC has to be explored still more to gain a better understanding. The present study can thus address the effect of EPFA substitution in combination with polycarboxylate ether based chemical admixture on specific properties of SCC, thereby assisting in the development of EPFA based SCC admixtures providing sustainability in construction.

\section{Experimental Studies}




\subsection{Materials}

Ordinary Portland Cement(OPC) was owned in the present study conforming to IS 12269[29]. Electrically precipitated Fly Ash (EPFA) gathered from Dr Narla Tata Rao Thermal Power Plant located at Ibrahimpatnam, near Vijayawada, Andhra Pradesh. The by-product obtained from the thermal power plants are comes under pollutants. These pollutants will be collected by using several methods. Fabric filters, Cyclones, Electrostatic precipitators, Wet and dry scrubbers, Condensation are some of the methods. The selection of the method will depend upon the type and particle size of the pollutant. In thermal power plants and cement industries, fabric filters and electrostatic precipitators are being used. Majority of thermal plants were using electrostatic precipitators for the pollutant collectors called fly ash. Fly ash collected with the help of electrostatic precipitator is named as Electrically Precipitated Fly Ash. EPFA is a very fine powder with low particle size and is hazardous to the human respiratory system. The microstructure of both the materials was analyzed by using Scanning Electron Microscope (SEM) fig.01. It is clearly noted that microstructure of EPFA is purely spherical and cement is irregular. The chemical composition of the binders was represented in Table 1 and is obtained by EDS analysis as shown in Fig 1. From the chemical analysis, it was identified that the obtained EPFA obtained belongs to the category of low calcium ash.

Table.01: Chemical composition of Cement and EPFA

\begin{tabular}{|lllllllll|}
\hline Composition\% & $\mathrm{SiO}_{2}$ & $\mathrm{Al}_{2} \mathrm{O}_{3}$ & $\mathrm{CaO}$ & $\mathrm{Fe}_{2} \mathrm{O}_{3}$ & $\mathrm{MgO}$ & $\mathrm{SO}_{3}$ & $\mathrm{~K}_{2} \mathrm{O}$ & L.O.I \\
Cement & 20.08 & 2.49 & 60.64 & 4.81 & 0.5 & 1.64 & 0.71 & 2.29 \\
\hline EPFA & 69.04 & 11.77 & 0.35 & 1.74 & 0.33 & - & 0.86 & 1.98 \\
\hline
\end{tabular}

Sound quality aggregates were procured and were used in this investigation. Crushed stone of nominal size $12.5 \mathrm{~mm}$ and naturally occurred sedimented sand was used as fine aggregate of maximum size $4.75 \mathrm{~mm}$ graded as Zone-II as per IS383, and particle distribution of aggregates were shown in Fig.02. Specific gravities of coarse and fine aggregates were calculated according to IS 2386 and obtained values of 2.72 and 2.64 respectively listed in table 02 . The used superplasticizer is a new range high water reducing agent, an acrylic polymer that can disperse cement particles more effectively by the adsorption of the acrylate chains together with the hindrance effects of the carboxyl group and specifications as per IS 9103-1999[30] listed in table 03 given by the manufacturer [31].

Table 02 Properties of materials. 


\begin{tabular}{|lllll|}
\hline Material & $\begin{array}{l}\text { Fineness } \\
\text { modulus }\end{array}$ & $\begin{array}{l}\text { Specific } \\
\text { Gravity }\end{array}$ & $\begin{array}{l}\text { Fineness \% (retained } \\
\text { on } 90 \mu \text { ) }\end{array}$ & $\begin{array}{l}\text { Fineness \% (retained } \\
\text { on } 45 \mu \text { ) }\end{array}$ \\
\hline Cement(C) & - & 3.12 & 5 & - \\
\hline EPFA(F) & - & 2.34 & - & 15 \\
\hline $\begin{array}{l}\text { Fine } \\
\text { Aggregate(FA) }\end{array}$ & 2.78 & 2.64 & - & - \\
\hline $\begin{array}{l}\text { Coarse } \\
\text { Aggregate(CA) }\end{array}$ & 7.41 & 2.72 & - & - \\
\hline
\end{tabular}

Table. 03 Properties of superplasticizer

\begin{tabular}{|ll|}
\hline Properties & Superplasticizer \\
\hline Colour & Beige \\
\hline Specific Gravity & 1.1 \\
\hline Active Ingredients & $40 \%$ \\
\hline Chemical Composition & Polycarboxylate ether \\
\hline $\mathrm{pH}$ & $6-8$ \\
\hline Recommended dosage & $0.4-1.8 \%$ \\
\hline
\end{tabular}

\subsection{Mixture Proportions}

Seven different SCC mixtures were designed and named as C, CF5, CF10, CF15, CF20, CF25 and CF30 by EPFA replacement in cement at $0 \%, 5 \%, 10 \%, 15 \%, 20 \%, 25 \%$ and $30 \%$ respectively. All the mix details used for the study was represented in Table 04 . To determine the optimum dosage of superplasticizer, several trail mixes were conducted to reach the standards required for self-compacting properties by EFNARC standards[32].

Table.04 Mix proportions of SSC 


\begin{tabular}{|llllllll|}
\hline $\begin{array}{l}\text { Mix } \\
\text { Name }\end{array}$ & $\begin{array}{l}\mathrm{C} \\
\left(\mathrm{kg} / \mathrm{m}^{3}\right)\end{array}$ & $\mathrm{F}\left(\mathrm{kg} / \mathrm{m}^{3}\right)$ & $\begin{array}{l}\mathrm{FA} \\
\left(\mathrm{kg} / \mathrm{m}^{3}\right)\end{array}$ & $\begin{array}{l}\mathrm{CA} \\
\left(\mathrm{kg} / \mathrm{m}^{3}\right)\end{array}$ & $\begin{array}{l}\text { Water/Powder } \\
\text { ratio }\end{array}$ & $\begin{array}{l}\text { Water } \\
\left(\mathrm{l} / \mathrm{m}^{3}\right)\end{array}$ & $\begin{array}{l}\mathrm{SP} \\
\left(\mathrm{I} / \mathrm{m}^{3}\right)\end{array}$ \\
\hline $\mathrm{C}$ & 550 & 0 & 925 & 779 & 0.3 & 165 & 2 \\
\hline CF5 & 522.5 & 27.5 & 920 & 776 & 0.3 & 165 & 2 \\
\hline CF10 & 495 & 55 & 916 & 772 & 0.3 & 165 & 2 \\
\hline CF15 & 467.5 & 82.5 & 912 & 769 & 0.3 & 165 & 2 \\
\hline CF20 & 440 & 110 & 908 & 765 & 0.3 & 165 & 2 \\
\hline CF25 & 412.5 & 137.5 & 904 & 762 & 0.3 & 165 & 2 \\
\hline CF30 & 385 & 165 & 900 & 759 & 0.3 & 165 & 2 \\
\hline
\end{tabular}

\section{Experiments}

\subsection{Setting Times:}

The time taken by cement paste to lose its plasticity was determined by initial setting time and final setting time. The setting times were determined for the cement paste with considering as well as without considering fly ash. The influence of fly ash on setting times was determined as per the IS4031 (part5)-1988[33]

The effect on the outcome of chemical and mineral admixtures on the initial and final setting time were estimated with the use of Polycarboxylate ether based superplasticizer, which helps to boost the workability.

\subsection{Fresh Properties:}

SCC mix should have fresh properties indicated in the EFNARC standards. i.e., filling ability, passing ability, flowing ability. These tests were executed on all the mixes and tested in order of Slump flow, measuring of $T_{50}$ time, $V$-funnel test, U-box and L-box test.

\subsection{Mechanical Properties:}

\subsubsection{Compression Test:}

Minimum of three specimens were cast with the size the $150 \times 150 \times 150 \mathrm{~mm}$ from each concrete mix. Tests were conducted as per the code IS:516-1959[34]. Compressive strength of the concrete as a maximum resistance offered by the concrete against deformation. It was determined at multiple ages( 3 , 7, 28 and 56days.).

\subsubsection{Splitting Tensile Strength Test:}


Splitting tensile strength of SCC was tested on three samples of each mix. A cylinder of $150 \mathrm{~mm}$ diameter, $300 \mathrm{~mm}$ length and tested as per code IS: 5816-1999[35]. Split tensile strength was determined at multiple ages $(3,7,28$, and 56 days).

\subsubsection{Flexural strength test:}

The flexural strength of SCC was measured using the test method according to IS: 516-1959[11]. The average of three samples were measured the flexural behavior of SCC with and without taking into account of admixtures.

\subsection{Durability Properties:}

\subsubsection{Rapid Chloride lon Permeability Test(RCPT):}

As per ASTM C 1202[36], the concrete specimen was prepared to the size of $100 \mathrm{~mm}$ diameter with $50 \mathrm{~mm}$ thick. It was conducted on samples from each mix to know the resistance over chloride ion penetration. This will show the relation of corrosion of the reinforcement in concrete [14]. The apparatus consists of two chambers; one is used as a cathode and the other as anode chambers. $3 \% \mathrm{NaCl}$ solution is filled in the cathode chamber, and $0.3 \mathrm{M} \mathrm{NaOH}$ solution is used in the anode chamber. The cumulative charge passed through the sample in coulombs will show the chloride ion penetration resistance. The charge passed through the specimens were noted up to 6 hours at 30 minutes interval.

\subsubsection{Sorptivity:}

The test specimens were oven-dried at $105^{\circ} \mathrm{C}$ up to the attainment of constant weight. After that, the cross-sectional area, as well as the weights, were measured. The specimens were submerged in a plastic tray to a depth of $2 \mathrm{~mm}$ from the bottom. And a plastic tube was used to maintain the required depth. Specimens were taken out from the tray, and weigh were noted at the interval of $1,5,10,30,60$, and 120 min up to 6 hours with an interval of 1 hour. The water absorption rate was represented in the initial as well as the secondary absorption rate. In this paper, the initial absorption rate was forecasted by using the below equation.

$$
s=\frac{i}{\sqrt{t}}
$$

Where $i=$ quantity of water absorbed in $\mathrm{mm}$

$t=$ time in sec, of a specimen placed in water tray at a depth of $2 \mathrm{~mm}$.

\section{Results And Discussions}

\subsection{Initial and final setting times:}


Fly Ash in cement retarded the setting times of cement; by the increase of fly ash content, setting time also increases[37][38]. In addition to that, the superplasticizer lapses both the setting times. Initial setting time of cement with 0\% EPFA and with 30\% EPFA replacement had a time-lapse of more than one hour. The final setting time of EPFA included cement also shows retardation of approximately two hours, which was represented in fig. 03. Retardation of setting times may be due to the generation of the low rate of hydration and also depends upon $\mathrm{Si} / \mathrm{Al}$ ratio. Si/Al ratio of EPFA is about 6.27 , which is considered as high. This high presence of soluble silica reaction takes more time to set. With the increase of EPFA content in the cement replacement, $\mathrm{Si} / \mathrm{Al}$ ratio also increases. This leads to the high setting times in both initial and final settings[47].

SCC is achieved with the addition of a superplasticizer; this SP also showed a notable effect on setting times. Firstly, the initial setting time of cement with only SP had noted, which was observed that the initial setting time could be more than the final setting time of cement without fly ash as well as SP. Secondly, for each mix from $0 \%$ to $30 \%$, EPFA in addition to SP shows a very high lapse of setting times. Inhibition of reactive sites through dispersion is the working mechanism of SP. With the effect of this mechanism, the fluidic nature has increased and also setting times has been increased than normal cement paste. The behavior of partially replaced cement with EPFA and SP on the setting times was presented in fig.04

\subsection{Fresh Properties of SCC:}

In the present study by addition of EPFA, slump flow values vary from $680 \mathrm{~mm}$ to $750 \mathrm{~mm}$. CF30 reaches the maximum flow and, mix $\mathrm{C}$ shows the minimum requirement as specified by the EFNARC standards. Due to the absorption of SP by cement particles, inhibition of reactive sites takes place. Dispersion is more for this type of mechanism when compared with other types of superplasticizer. This mechanism helps the concrete to achieve more fluidic nature at very low dosages. In addition to this, the EPFA combination increased the fresh properties of SCC because of its spherical shaped microstructure. Simultaneously, V-funnel takes a maximum time of $9.35 \mathrm{sec}$ for mix $\mathrm{C}$ and, mix CF30 takes only $7.56 \mathrm{sec}$. The effect of mineral admixture on filling ability was presented in the fig.05. workability results are similar to M.sahmaran.et.al.[39]. The minimum requirement for L-Box to reach the SCC standards is 0.8 . All the mixes were satisfied with the basic requirements of SCC. L-Box depth ratios were varied from 0.8 to 0.85 . $\mathrm{U}$ - Box height difference varies from $28-21 \mathrm{~mm}$. It was observed that by the increase of fly ash, the fresh properties of SCC were increased.

\subsection{Mechanical Properties}

\subsubsection{Compression Test:}

Compressive strength of conventional and partially replaced SCC by fly ash was studied at multiple ages $(3,7,28$, and 56 days). EPFA was replaced at $5 \%, 10 \%, 15 \%, 20 \%, 25 \%$ and $30 \%$ levels. The statistical data shows that the change in compressive strength was increased[40]. Mechanical properties were reduced 
by the increment of EPFA content at early ages( 3 and 7 days). On the other hand, 28 and 56 days raise compressive strength from $68.6 \mathrm{MPa}$ to $85.64 \mathrm{MPa}$ for the CF20 mix. The effect of partially replaced EPFA on the compressive strength of SSC are presented in fig.07.The compressive strength of high strength self compacting concrete at early ages was affected may be due to EPFA particle sizes. The fineness of EPFA is low when compared with the cement, as elucidated through sem images of cement and EPFA in Fig 1. Due to these coarser particles present in ash may delay the reactivity of EPFA, which helps to the production of secondary C-S-H gels in the concrete matrix; thereby, the compressive strength has been improved with enhanced/prolonged curing periods [16].

CF20 performs high strength among all mixes. From $5 \%$ to $20 \%$, values have been increased, beyond $20 \%$ fly ash strength gets reduced. At 25 and 30 percent, fly ash results are similar to Dadsetan.et.al.[41]. N.Sing. et al. reviewed the usage of fly ash as a mineral admixture, made similar conclusions to this study[16].

\subsubsection{Splitting tensile strength:}

The outcomes of split tensile strength test at 3 days, 7 days, 28 days and 56 days were presented in fig.08. Which ranges from 2.29 to $4.56 \mathrm{MPa}$. The maximum tensile strength was observed in CF20, the changes in strengths of CF5, CF10, CF15, CF20, CF25 and CF30 are decreased for 3 days and 7 days with mix C. This decrement may be due to the slow rate of reaction caused by EPFA. At the ages of 28 days, the increment of tensile strength is restricted to 4.20MPa for CF20 mix. Beyond this mix, values get decreased more than the conventional mix. Calcium ions present in calcium hydroxide $(\mathrm{CH})$ reacts with EPFA to form secondary $\mathrm{C}-\mathrm{S}-\mathrm{H}$, which is the binder phase. This secondary $\mathrm{C}-\mathrm{S}-\mathrm{H}$ results in the enhancement of splitting tensile strength at later ages. However, concrete with replacement at early ages not able to gain its strength due to low amount of $\mathrm{C}-\mathrm{S}-\mathrm{H}$ and $\mathrm{CH}$. It was observed that 56 days have a minimum of $4.21 \mathrm{MPa}$ for $\mathrm{C}$ mix and maximum obtained for CF20. The data regarding the split tensile strength of concrete, as shown in fig.08. Split tensile strength varies its values from $5.5 \%$ to more than $6 \%$ of compressive strength. From the graphical representation, it may conclude that very low increment was shown with compressive strength.

\subsubsection{Flexural Strength:}

The flexural strength of concrete was determined, and the results were presented in fig.09. At 3, 7, 28, and 56 days, with respective to C, CF20 shows low strength at 3 and 7 days whereas, at 28,56 days it was more. CF20 has increased about 1.05 times the flexural strength of CF0 at 28 days and 1.1 times at 56 days. For SCC, flexural strength performed in this study is high when compared to conventional vibration concrete. The development of flexural strength of EPFA based SCC at later ages is due to the reactivity of silica present in EPFA. The reactive silica reacts with $\mathrm{CH}$, which is a hydration product of cement. The early age strength reduction may be due to lack of calcium hydroxide because of low cement content after replacement. At 56 days, CF5, CF10, CF15, CF20 mixes were gained strengths $1.65 \%, 3.42 \%, 4.64 \%$, $11.3 \%$ respectively when compared conventional mix at 28 days. $31.2 \%$ for 3 days and $29.48 \%$ for 7 days 
strengths were reduced from C mix to CF30 mix. On the other hand, at 56 days age, CF30 lost its strength by $13 \%$ only.

\subsection{Durability Properties:}

\subsubsection{RCPT:}

Rapid Chloride penetration test was conducted on all the concrete mixes. The observations were presented in fig.09. The cumulative charge passed through the samples in coulombs was noted at the interval of $30 \mathrm{~min}$ up to 6hours. As per the code ASTM C 1202, when the charge passed is less than 1000 , then the chloride penetration is very low, and if it is greater than 4000 , then it is high. In this study, SCC shows low penetration of chloride and by the increase of fly ash content up to $20 \%$ by mass decreases (Very low(i.e., <1000)) the penetration, but after 20\% (i.e., CF25 and CF30) it shows increases in penetration but not greater than convention mix(i.e., C)[42]. The pozzolanic reaction of EPFA with $\mathrm{Ca}(\mathrm{OH})_{2}$ can be attributed for this minimal chloride penetration in the concrete. Also, the fines content present in EPFA can assist in the discontinuity of the porous network reducing the chloride penetration. The total charge passed for all the concrete mixes lie under the category of 'very low' and 'low' as per ASTM C1202standards [36]. Mix C exhibits low penetration of chloride. Usage of admixtures reduced penetration up to $50 \%$ at the optimum mix.

\subsubsection{Sorptivity:}

The initial rate of absorption was studied on all concrete mix samples. The quantity of water absorbed by all the concrete samples was equal at the same age, i.e., 28 days. Effect of mineral admixture on sorptivity of concrete was presented by the fig.11.a to fig.11.g., by plotting the graph between water absorbed $(i)$ in $\mathrm{mm}$ and the square root of time $\left(\sec ^{1 / 2}\right)$. The graphical trends are similar to the results of H.Y.Leung[43]. Fig.11.a shows the initial rate of absorption for OPC cement concrete (conventional mix), which is high when compared to other mixes.

Due to the increase of EPFA content from $0 \%$ to $30 \%$ in the cement content, initial absorption noted at 28 days was decreased by $15 \%$ due to the fineness of fly ash. Very fine particles of fly ash fill the pores of the cement paste, which may lead to the reduction of capillary rise in pores. When EPFA content increased, the sorptivity effect of SCMs with replacement decreased. The formation of secondary hydration products by utilization of the high water holding capacity of EPFA attributes to the decrement in the sorptivity values. The compressive strength of concrete is inversely proportional to the porosity of the concrete, and thus the reduction in voids contributes to the strength improvement as stated above.

In the fig.11.a., it was observed that a linear graph coincides with an actual curve, which means the initial absorption was increased with time. Same graphical trends were followed in fig.11.d and fig.11.e., but in fig.11.f and fig.11.g, the cumulative water absorbed is constant at 60 and $120 \mathrm{~mm}$. Fly ash beyond $20 \%$ in cement shows high resistance to initial absorption. 


\section{Conclusions}

All the mixes were satisfied with the standards are given by EFNARC for SCC. Workability has increased by the usage of mineral and chemical admixtures. With the additions of EPFA in SCC, the setting times of the SCC were altered significantly. The delayed setting times can thus make the SCC mixes much more workable, thus attaining SCC requirements. The EPFA also contributed significantly towards filling the pores and the formation of secondary hydration products, which increased the strength of the concrete. The porosity of the concrete was also decreased with reduced capillary absorption leading to less sorptivity values. Overall the durability and mechanical performance of the SCC increased with the additions of EPFA in the concrete. Also, the specimens exposed to chloride penetration showed higher resistance with increased EPFA proportions. At the optimum dosage of mineral admixture, the charge passed through the specimen was very low

Thus, it can be concluded that the EPFA additions in self compacting concrete at optimum percentages can develop a concrete that is sustainable and also can counterbalance the pollution due to increasing deposition of EPFA in the environment through exploitation through effective utilization.

\section{Declarations}

ETHICS APPROVAL AND CONSENT TO PARTICIPATE: Not applicable

CONSENT FOR PUBLICATION : Not Applicable

AVAILABILITY OF DATA AND MATERIAL:

The authors confirm that the data supporting the findings of this study are available within the article

\section{COMPETING INTEREST:}

The Authors declares that there is no conflict of interest

FUNDING STATEMENT:

None. No funding to declare

\section{AUTHORS CONTRIBUTION:}

Mr.SA contributed to the design and implementation of the research, to the analysis of the results and to the writing of the manuscript. Dr.EA supervised the project and evaluated the results. All authors read and approved the final manuscript.

ACKNOWLEDGMENTS: 
Authors thank to Gudlavalleru Engineering College, Gudlavalleru, Andhra Pradesh, India for providing experimental setup to conduct experiments required for research.

\section{References}

1. K. Kuder, D. Lehman, J. Berman, G. Hannesson, and R. Shogren, (2012)Mechanical properties of self consolidating concrete blended with high volumes of fly ash and slag, Constr. Build. Mater., https://doi.org/10.1016/j.conbuildmat.2012.02.034.

2. M. Mosheraju and S. Arunchaitanya, (2015) Experimental Investigation of Copper Slag as Partially Replacement of Fine Aggregate and Fly Ash as Cement in Concrete, Available: www.ijsr.net.

3. S. Arunchaitanya and E. Arunakanthi, (2019) Usage of Mineral Admixtures in Self Compacting Concrete-A Review,.

4. K. R. Kumar, G. Shyamala, P. O. Awoyera, K. Vedhasakthi, and O. B. Olalusi, (2020)Cleaner production of self-compacting concrete with selected industrial rejects-an overview, Silicon, https://doi.org/ $10.1007 / \mathrm{s} 12633-020-00636-6$.

5. M. Liu, (2010)Self-compacting concrete with different levels of pulverized fuel ash, Constr. Build. Mater., https://doi.org/ 10.1016/j.conbuildmat.2009.12.012.

6. E. Janowska-Renkas, (2013)The effect of superplasticizers' chemical structure on their efficiency in cement pastes, Constr. Build. Mater., https://doi.org/ 10.1016/j.conbuildmat.2012.09.032.

7. F. R. Kong, L. S. Pan, C. M. Wang, D. La Zhang, and N. Xu, (2016)Effects of polycarboxylate superplasticizers with different molecular structure on the hydration behavior of cement paste, Constr. Build. Mater., https://doi.org/ 10.1016/j.conbuildmat.2015.12.178.

8. M. H. W. Ibrahim, A. F. Hamzah, N. Jamaluddin, P. J. Ramadhansyah, and A. M. Fadzil, (2015) Split Tensile Strength on Self-compacting Concrete Containing Coal Bottom Ash, Procedia - Soc. Behav. Sci., https://doi.org/ 10.1016/j.sbspro.2015.06.317.

9. S. D. Bauchkar and H. S. Chore, (2018)Effect of PCE superplasticizers on rheological and strength properties of high strength self-consolidating concrete, Adv. Concr. Constr., https://doi.org/ 10.12989/acc.2018.6.6.561.

10. M. Veerraju and S. Arunchaitanya, (2018)Experimental study on high strength self - Compaction concrete by using fly ash as a partial replacement of cement and copper slag with fine aggregate, Int. J. Innov. Technol. Explor. Eng., [Online]. Available: http://www.scopus.com/inward/record.url?eid=2s2.0-85058111789\&partnerID=MN8TOARS.

11. A. K. Parande, (2013) Role of ingredients for high strength and high performance concrete - A review, Adv. Concr. Constr., https://doi.org/ 10.12989/acc.2013.01.2.151.

12. M. Jalal, M. Fathi, and M. Farzad, (2013) Effects of fly ash and TiO2 nanoparticles on rheological, mechanical, microstructural and thermal properties of high strength self compacting concrete, Mech. Mater., https://doi.org/ 10.1016/j.mechmat.2013.01.010. 
13. Syed Mohammed Mustakim Shaswat Kumar Das, Jyotirmoy Mishra, Asif Aftab, Thamer Salman Alomayri, Hasan Suliman Assedi and Cyriaque Rodrigue Kaze, (2020)Improvement in Fresh, Mechanical and Microstructural Properties of Fly Ash- Blast Furnace Slag Based Geopolymer Concrete By Addition of Nano and Micro Silica, Silicon,https://doi.org/ 10.1007/s12633-020-005930.

14. P. Dinakar, K. G. Babu, and M. Santhanam, (2008) Mechanical properties of high-volume fly ash selfcompacting concrete mixtures, Struct. Concr., https://doi.org/ 10.1680/stco.2008.9.2.109.

15. S. D. Bauchkara and H. S. Chore, (2017)Experimental studies on rheological properties of smart dynamic concrete, Adv. Concr. Constr., https://doi.org/ 10.12989/acc.2017.5.3.183.

16. N. Singh, P. Kumar, and P. Goyal, (2019)Reviewing the behaviour of high volume fly ash based self compacting concrete, Journal of Building Engineering.,https://doi.org/ 10.1016/j.jobe.2019.100882.

17. K. Tabit, H. Hajjou, M. Waqif, and L. Saâdi, (2020)Cordierite-Based Ceramics from Coal Fly Ash for Thermal and Electrical Insulations, Silicon, https://doi.org/ 10.1007/s12633-020-00428-y.

18. P. Nath and P. Sarker, (2011) Effect of fly ash on the durability properties of high strength concrete,https://doi.org/ 10.1016/j.proeng.2011.07.144.

19. W. Wongkeo, P. Thongsanitgarn, A. Ngamjarurojana, and A. Chaipanich, (2014)Compressive strength and chloride resistance of self-compacting concrete containing high level fly ash and silica fume, Mater. Des., https://doi.org/ 10.1016/j.matdes.2014.07.042.

20. P. Ramanathan, I. Baskar, P. Muthupriya, and R. Venkatasubramani, (2013)Performance of selfcompacting concrete containing different mineral admixtures, KSCE J. Civ. Eng., https://doi.org/ 10.1007/s12205-013-1882-8.

21. R. Siddique, P. Aggarwal, and Y. Aggarwal, (2012)Influence of water/powder ratio on strength properties of self-compacting concrete containing coal fly ash and bottom ash, Constr. Build. Mater., https://doi.org/ 10.1016/j.conbuildmat.2011.10.035.

22. R. Siddique, (2011)Properties of self-compacting concrete containing class F fly ash, Mater. Des., https://doi.org/ 10.1016/j.matdes.2010.08.043.

23. Y. Xie, B. Liu, J. Yin, and S. Zhou, (2002)Optimum mix parameters of high-strength self-compacting concrete with ultrapulverized fly ash, Cem. Concr. Res., https://doi.org/ 10.1016/S00088846(01)00708-6.

24. B. Ma, M. Ma, X. Shen, X. Li, and X. Wu, (2014) Compatibility between a polycarboxylate superplasticizer and the belite-rich sulfoaluminate cement: Setting time and the hydration properties, Constr. Build. Mater., https://doi.org/ 10.1016/j.conbuildmat.2013.10.028.

25. A. Oner, S. Akyuz, and R. Yildiz, (2005) An experimental study on strength development of concrete containing fly ash and optimum usage of fly ash in concrete, Cem. Concr. Res., https://doi.org/ 10.1016/j.cemconres.2004.09.031.

26. J. Sim and C. Park, (2011) Compressive strength and resistance to chloride ion penetration and carbonation of recycled aggregate concrete with varying amount of fly ash and fine recycled aggregate, Waste Manag., https://doi.org/ 10.1016/j.wasman.2011.06.014. 
27. C. feng Lu, W. Wang, Q. tao Li, M. Hao, and Y. Xu, (2018)Effects of micro-environmental climate on the carbonation depth and the $\mathrm{pH}$ value in fly ash concrete, J. Clean. Prod., https://doi.org/ 10.1016/j.jclepro.2018.01.155.

28. A. Bagheri, H. Zanganeh, H. Alizadeh, M. Shakerinia, and M. A. S. Marian, (2013) Comparing the performance of fine fly ash and silica fume in enhancing the properties of concretes containing fly ash, Constr. Build. Mater., https://doi.org/ 10.1016/j.conbuildmat.2013.06.037.

29. Indian Standard Specification for 53 Grade Ordinary Portland Cement :IS 12269-1987

30. Indian Standard Concrete Admixtures- Specification: IS 9103-1999

31. Cera Hyperplast XR-W40 New Range Water Reducing Admixture: Manual by CERA CHEMICALS Superior Construction Chemicals

32. EFNARC, The European Guidelines for Self-Compacting Concrete,Eur. Guidel. Self Compact. Concr., no. May, p. 63, 2005, [Online]. Available: http://www.efnarc.org/pdf/SCCGuidelinesMay2005.pdf.

33. Indian Standard Methods of Physical Tests for Hydraulic Cement: Determination of Initial and Final Setting Times IS4031(Part-5)-1988.

34. Indian Standard Methods of Test for Strength of Concrete: IS 516-1959.

35. IS 5816: 1999, Indian standard Splitting tensile strength of concrete- method of test (first revision), Bur. Indian Stand. New Delhi, vol. (reaffirme, pp. 1-14, 1999.

36. American Society for Testing and Materials, ASTM C 1202-12, Standard Test Method for Electrical Indication of Concrete's Ability to Resist Chloride Ion Penetration

37. A. Durán-Herrera, C. A. Juárez, P. Valdez, and D. P. Bentz, (2011)Evaluation of sustainable highvolume fly ash concretes, Cem. Concr. Compos.,https://doi.org/ 10.1016/j.cemconcomp.2010.09.020.

38. A. Duran-Herrera, J. De-León-Esquivel, D. P. Bentz, and P. Valdez-Tamez, (2019) Self-compacting concretes using fly ash and fine limestone powder: Shrinkage and surface electrical resistivity of equivalent mortars, Constr. Build. Mater., https://doi.org/ 10.1016/j.conbuildmat.2018.11.191.

39. M. Şahmaran, I. Ö. Yaman, and M. Tokyay, (2009) Transport and mechanical properties of self consolidating concrete with high volume fly ash, Cem. Concr. Compos., https://doi.org/ 10.1016/j.cemconcomp.2008.12.003.

40. M. Uysal and M. Sumer, (2011)Performance of self-compacting concrete containing different mineral admixtures, Constr. Build. Mater., https://doi.org/10.1016/j.conbuildmat.2011.04.032.

41. S. Dadsetan and J. Bai, (2017)Mechanical and microstructural properties of self-compacting concrete blended with metakaolin, ground granulated blast-furnace slag and fly ash, Constr. Build. Mater., https://doi.org/ 10.1016/j.conbuildmat.2017.04.158.

42. M. Şahmaran, M. Lachemi, T. K. Erdem, and H. E. Yücel, (2011)Use of spent foundry sand and fly ash for the development of green self-consolidating concrete, Mater. Struct. Constr.,https://doi.org/ $10.1617 / \mathrm{s} 11527-010-9692-7$. 
43. H. Y. Leung, J. Kim, A. Nadeem, J. Jaganathan, and M. P. Anwar, (2016) Sorptivity of self-compacting concrete containing fly ash and silica fume, Constr. Build. Mater., https://doi.org/ 10.1016/j.conbuildmat.2016.03.071.

44. T.Rudnicki(2021) Functional method of designing self compacting concrete, Materials.,

45. Orava Hanne, Nordman Timo, Kuopanportti Hannu (2006) Increase the utilisation of fly ash with electrostatic precipitation. Minerals Enginnering., https://doi.org/10.1016/j.mineng.2006.07.002.

46. P Li, J Ran, D Nie, W Zhang (2021), Improvement of mix design methode based on paste rheological threshold theory for self-compacting concrete using different mineral additions in ternary blends of powders. Constr. Build. Mater., https://doi.org/10.1016/j.conbuildmat.2020.122194

47. Ahmer Ali Siyal, Khairun Azizi Azizli, Zakaria Man, Hafeez Ullah (2016), Effects of Parameters on the setting time of fly ash based geopolymers using taguchi method. Procedia Engg., https//doi.org/10.1016/j.proeng.2016.06.624

48. Anjaneya Babu Padavala, Malasani Potharaju, Venkata Ramesh Kode (2021), Mechanical properties of ternary blended mix concrete of fly ash and silica fume. Materials today Proceedings, https://doi.org/10.1016/j.matpr.2020.12.127

\section{Figures}




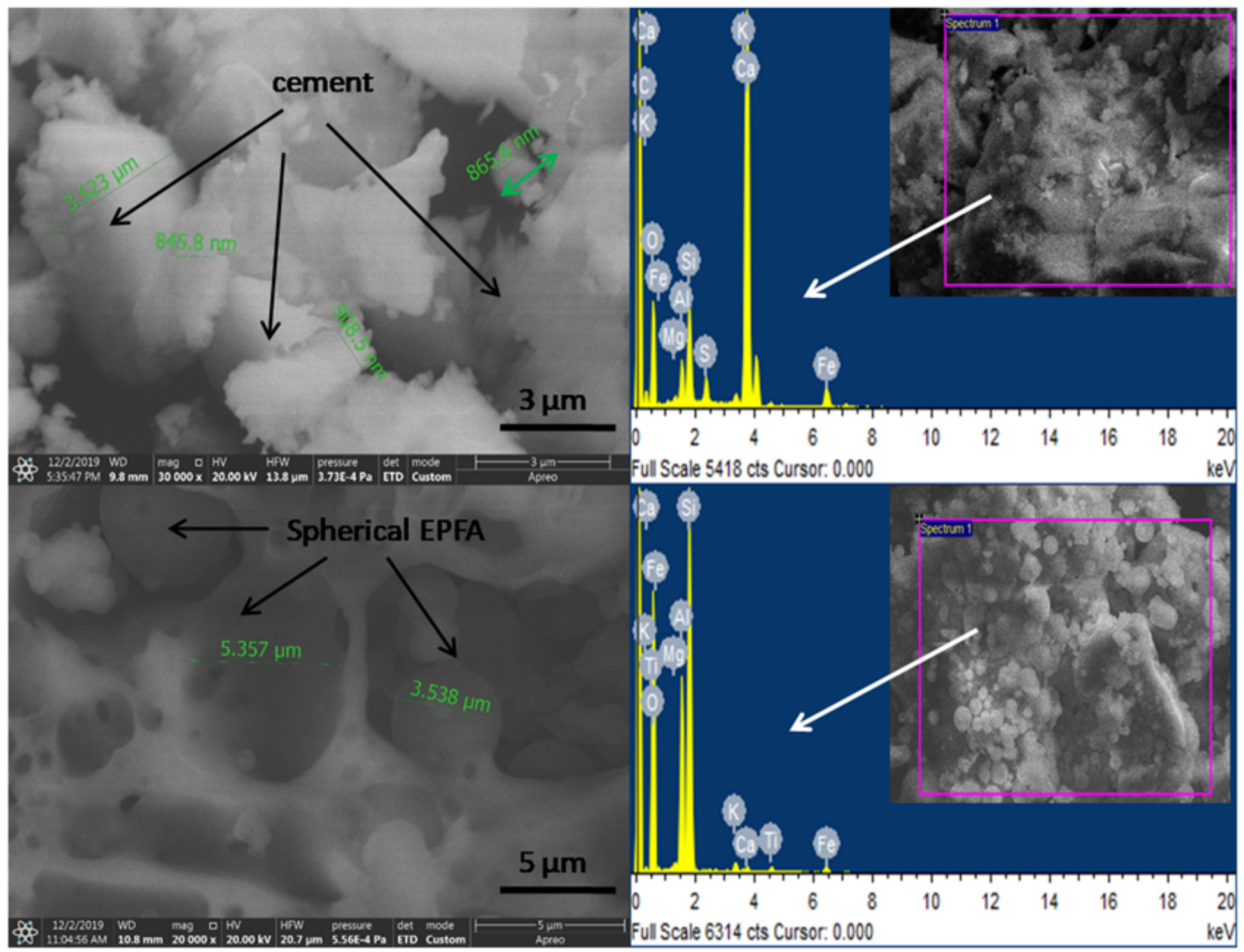

Figure 1

SEM and EDS images of Cement and EPFA. 


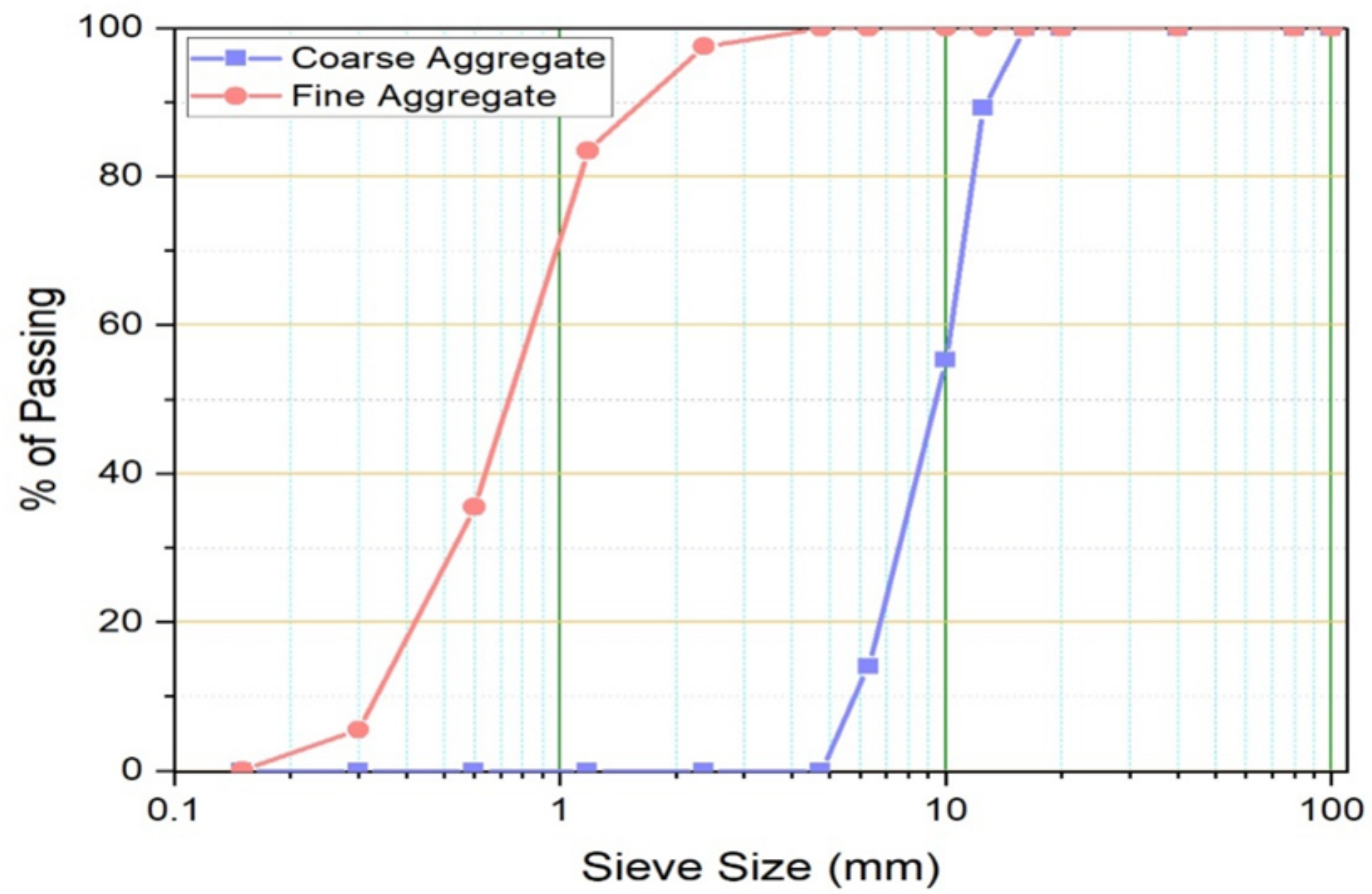

Figure 2

Grading of aggregates 


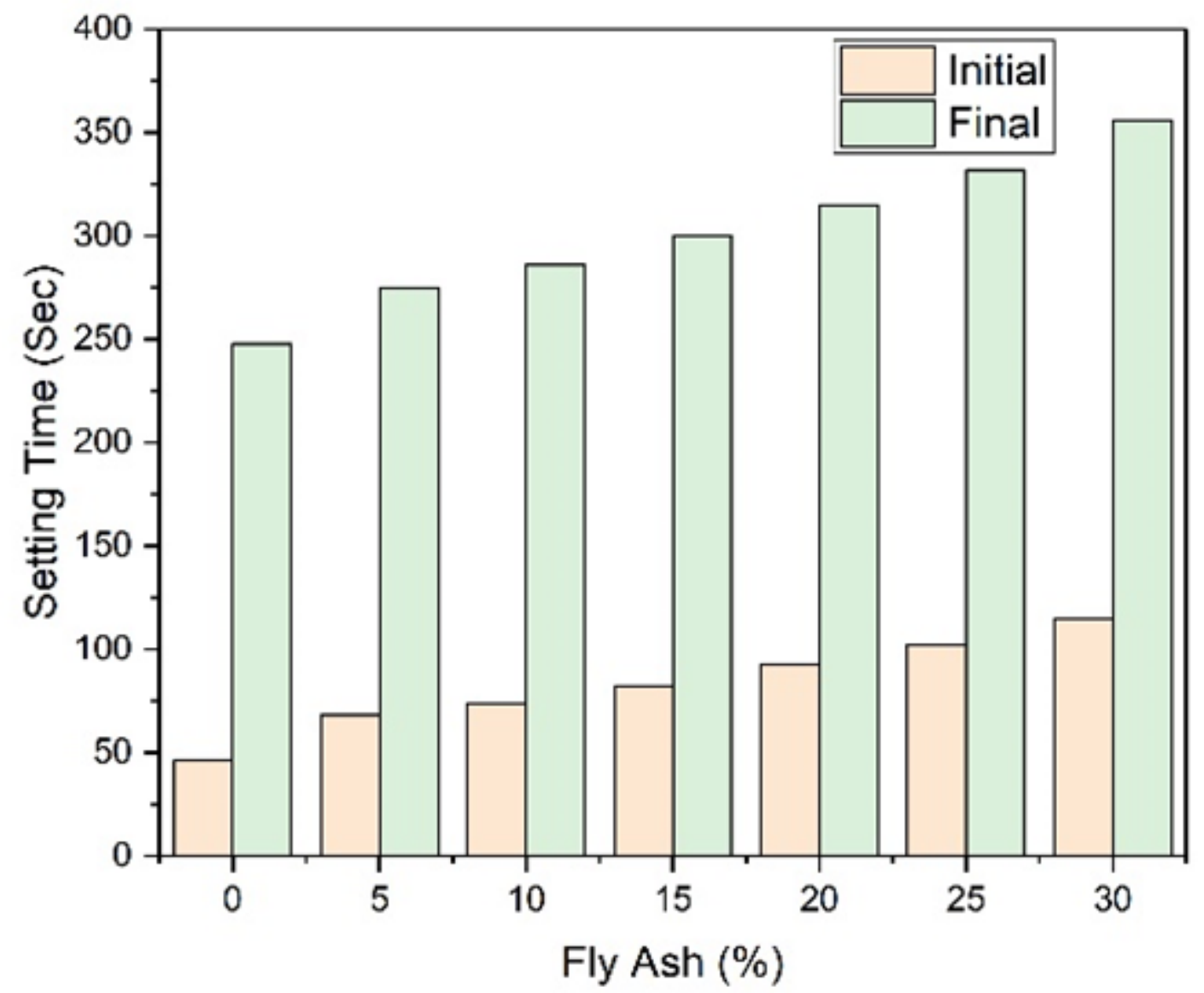

Figure 3

Setting times of Fly ash included cement. 


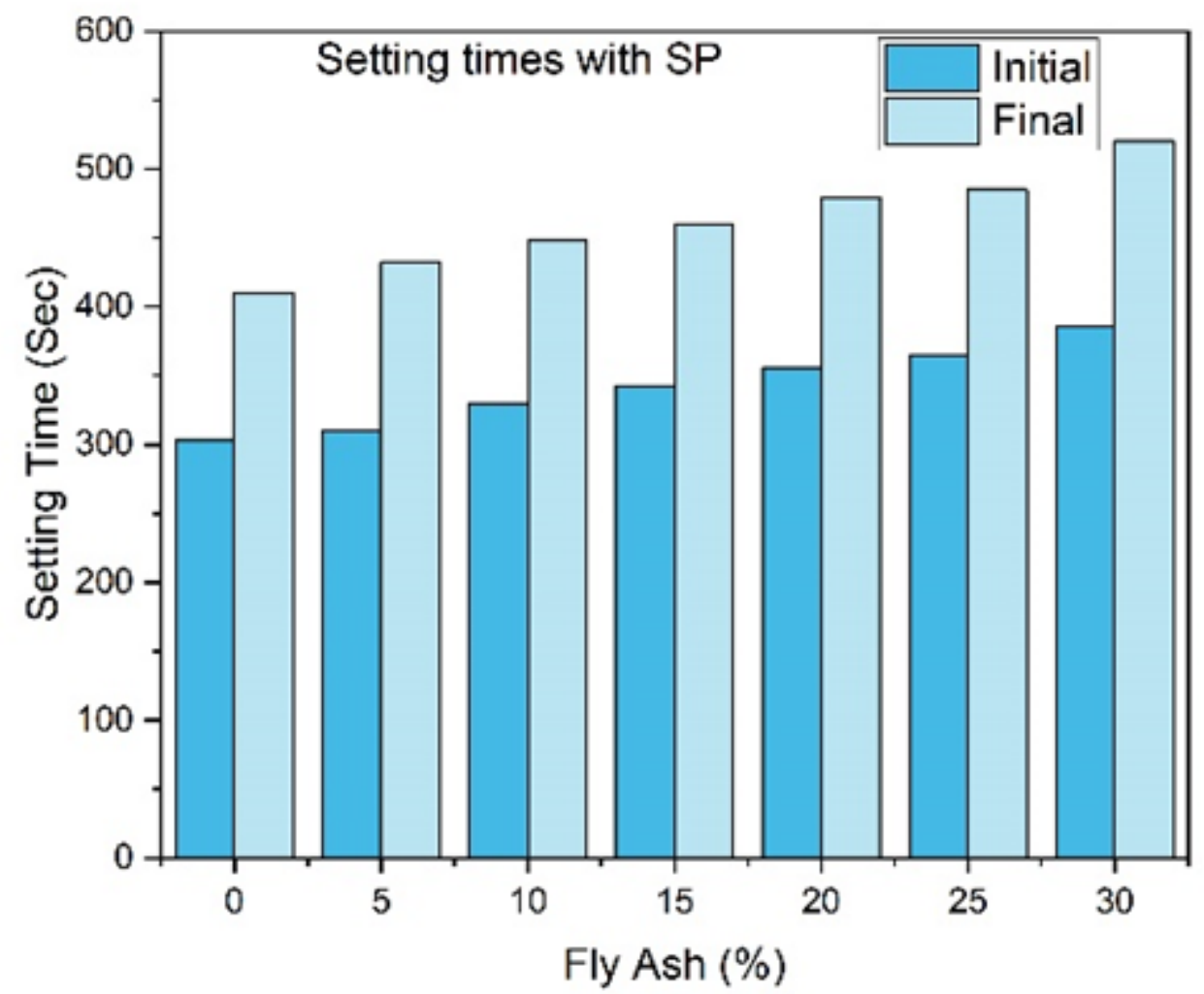

Figure 4

Setting times for cement with Fly ash\& SP.

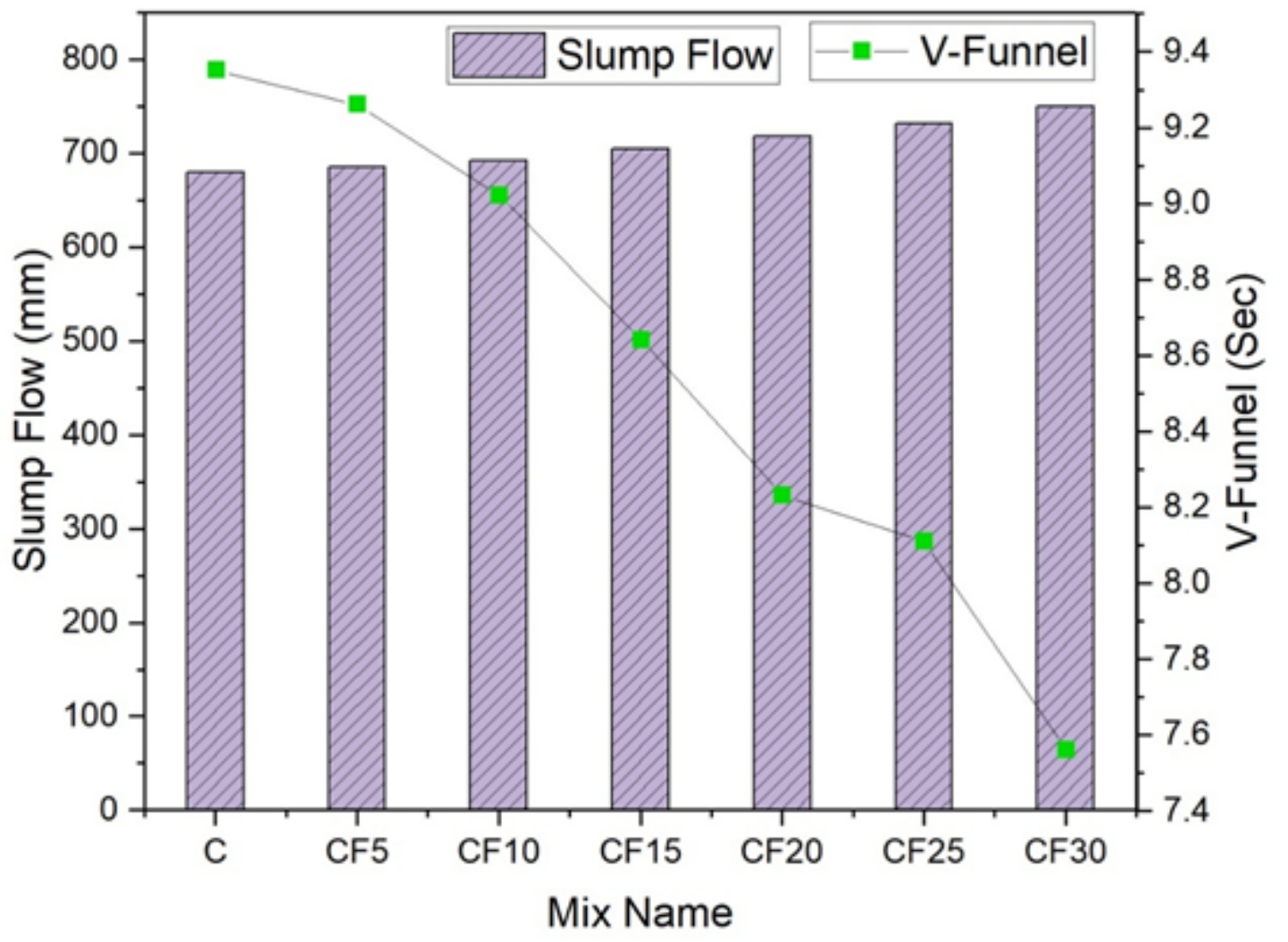

Figure 5 
Filling Ability of SCC.

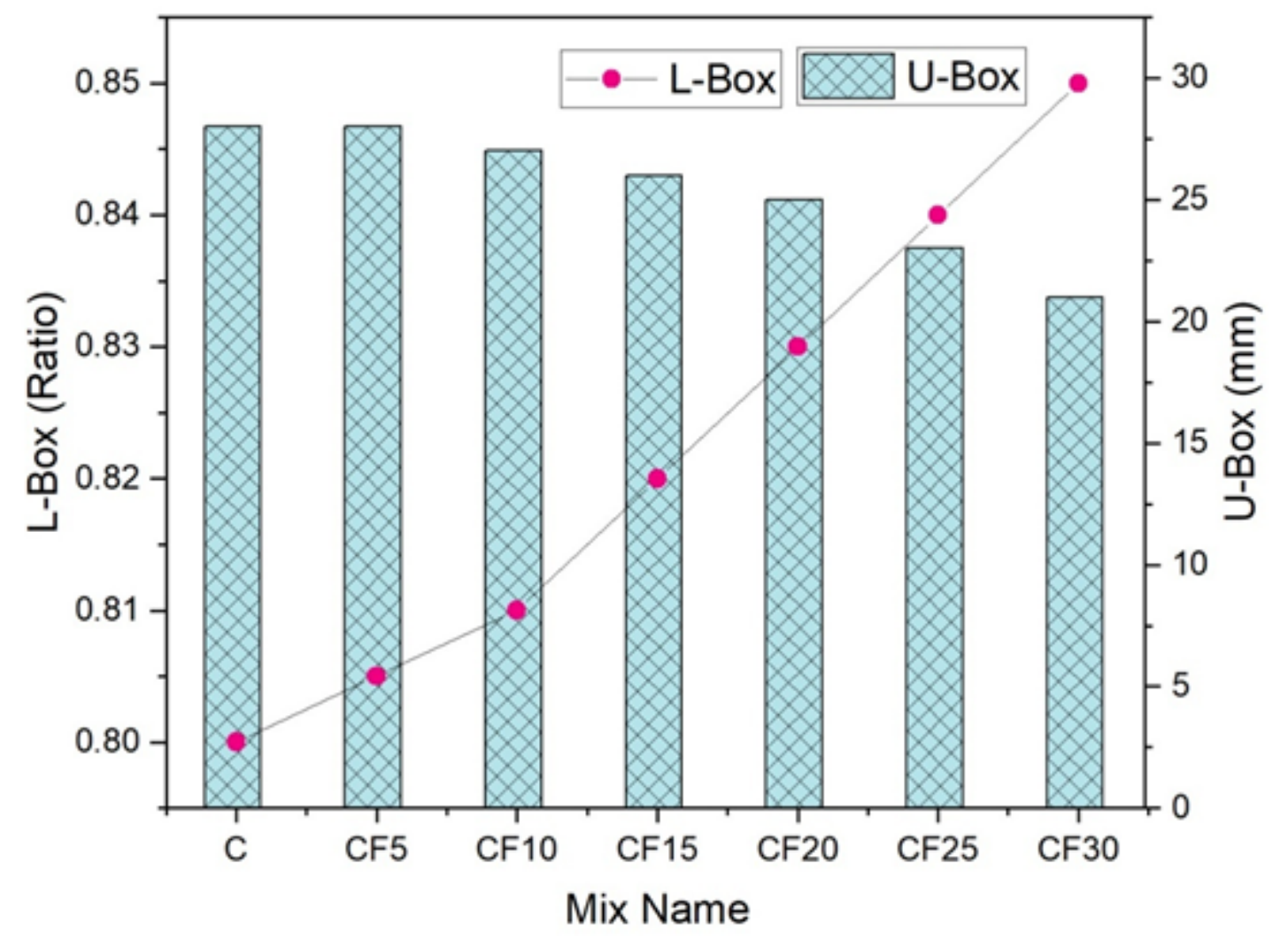

Figure 6

Passing ability of SCC. 


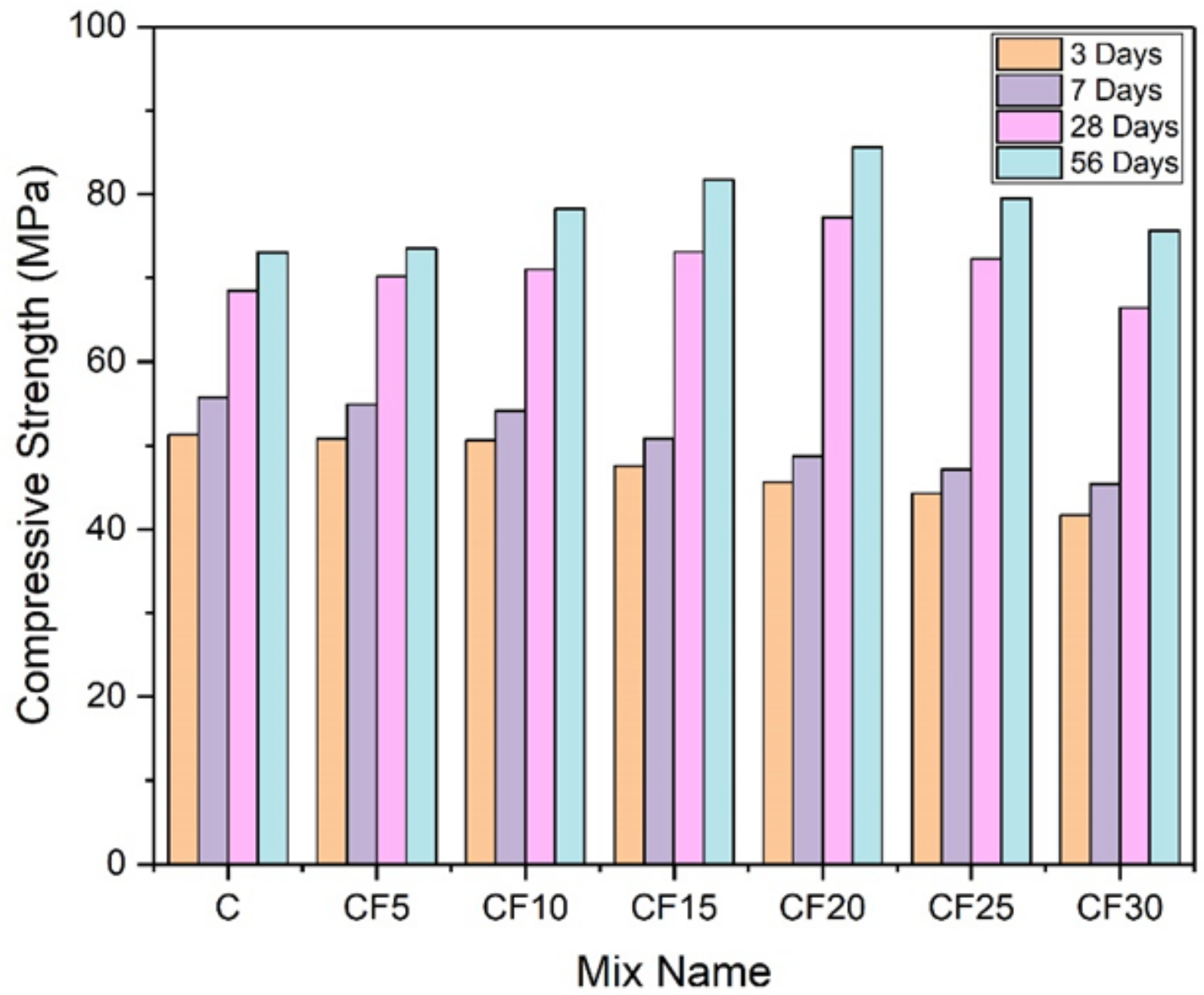

Figure 7

Compressive strengths of different SCC mixes 


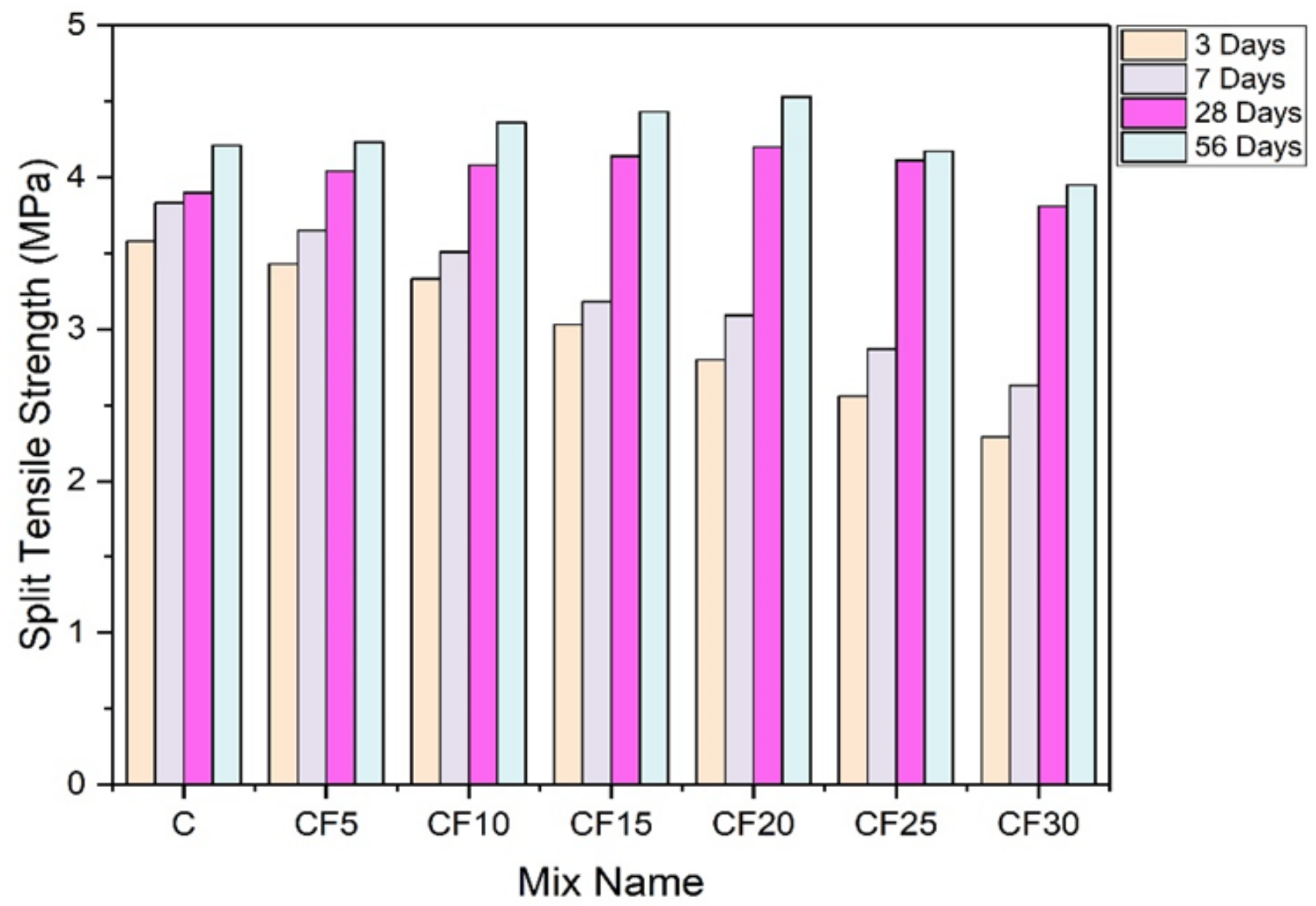

Figure 8

Results of split tensile strength of different SCC mixes. 


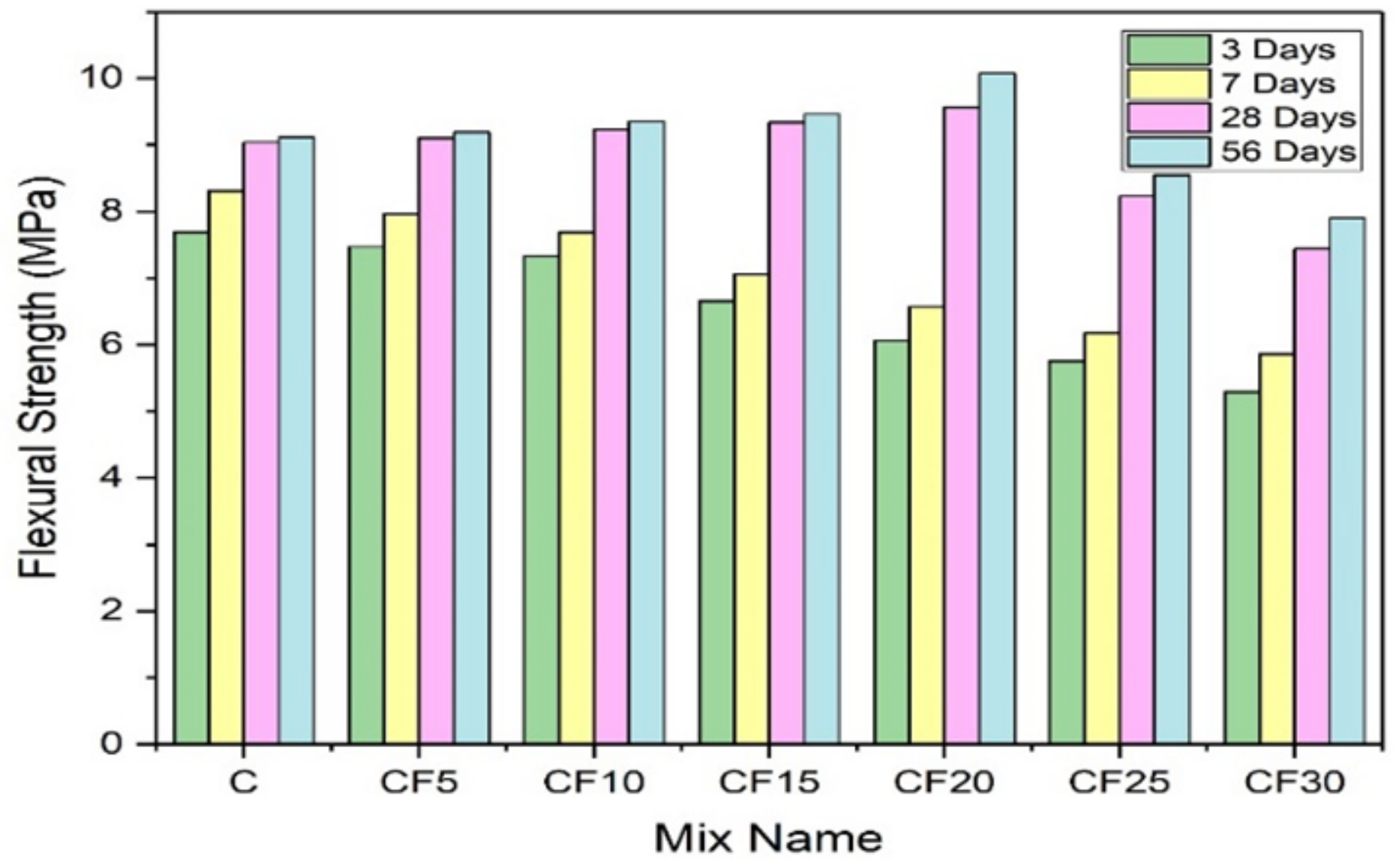

Figure 9

Flexural Strength results. 


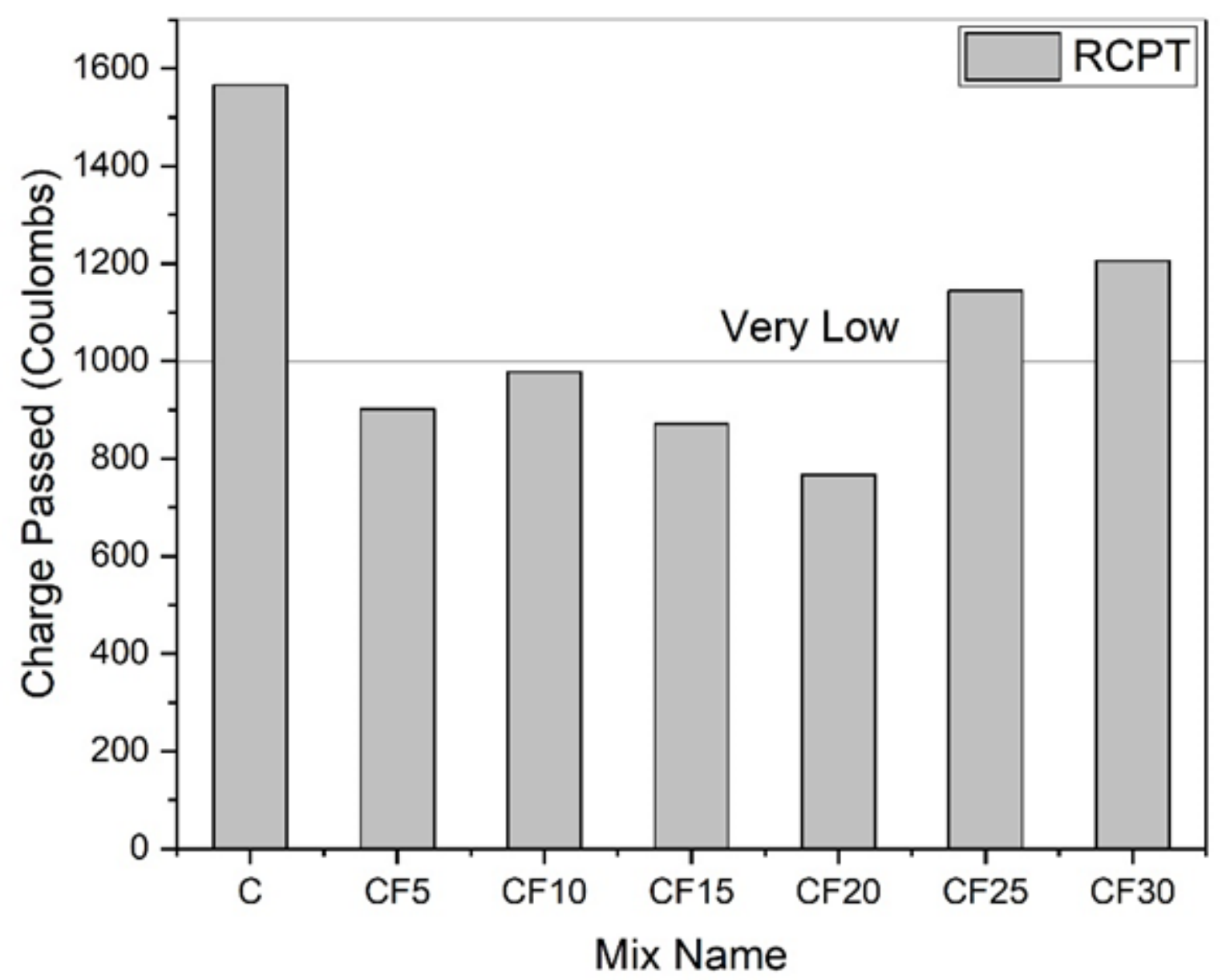

Figure 10

The charge passed through the specimen (RCPT) 


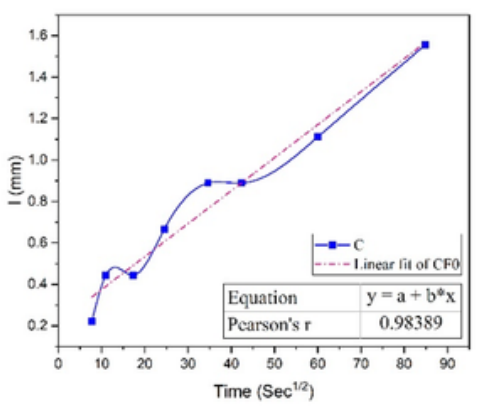

a

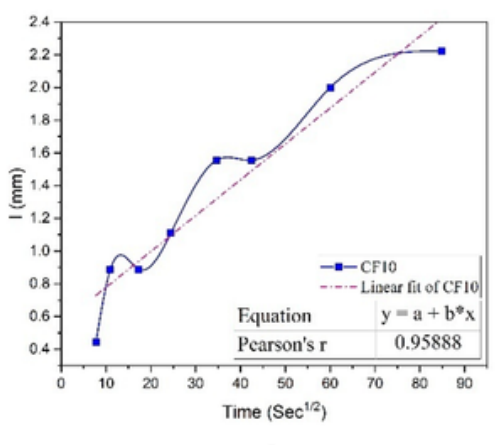

c

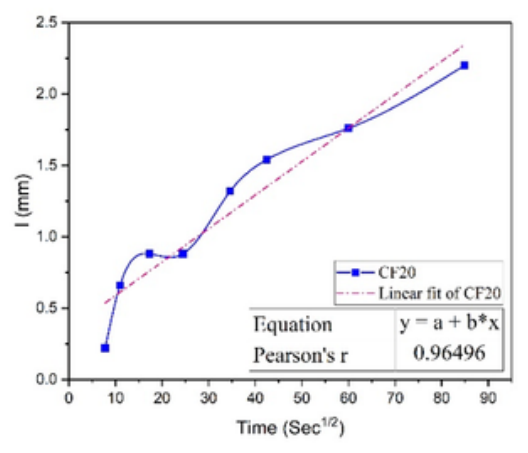

e

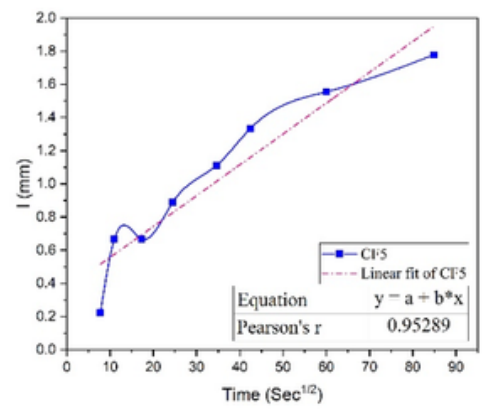

b

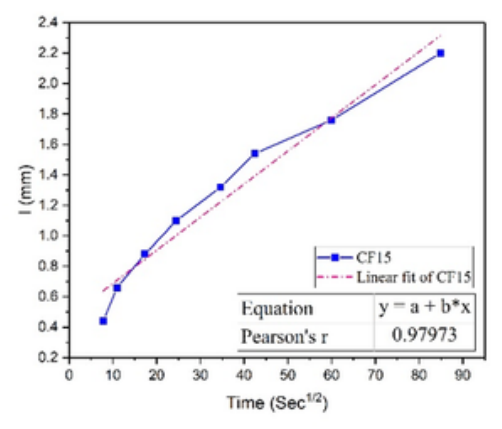

d

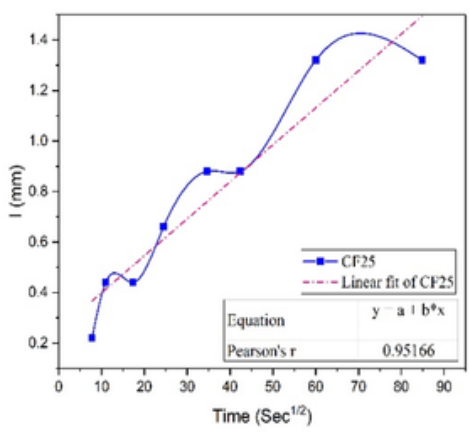

$\mathrm{f}$

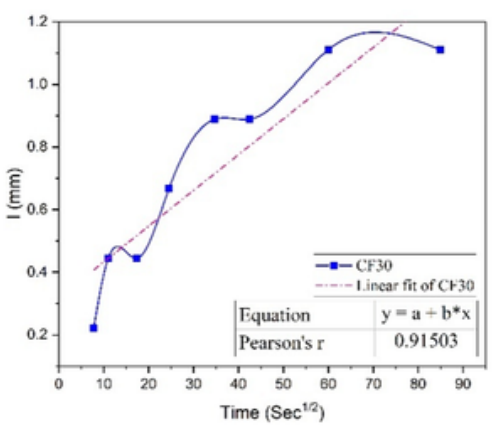

g

\section{Figure 11}

In the fig.11.a., it was observed that a linear graph coincides with an actual curve, which means the initial absorption was increased with time. Same graphical trends were followed in fig.11.d and fig.11.e., but in fig.11.f and fig.11.g, the cumulative water absorbed is constant at 60 and $120 \mathrm{~mm}$. Fly ash beyond $20 \%$ in cement shows high resistance to initial absorption. 